\title{
The Origin of the Frog Totem in Guangxi
}

\section{Bohai,Xu}

Address: Suzhou Industrial Park , Suzhou, China

Abstract: Maguai, which in Zhuang dialect means frogs, is considered the incarnations of gods by the Zhuang ethnic group. From the paper, you can speculate that Maguai God(Frog God) is actually Egyptian goddess Heqet in China. 
Maguai, which in Zhuang dialect means frogs, is considered the incarnations of gods by the Zhuang ethnic group.

In ancient times, Zhuang people would dress up as frogs, sing and dance to ask for peace, harmony and a good harvest, and this gradually developed into the Maguai Festival. The festival was included as one of China's national intangible cultural heritages in 2005.

The Zhuang people live in the hot and rainy areas of South China. They mainly rely on agriculture to survive. People are familiar with frogs. The frogs in the rice fields are used to kill insects and protect the harvest of rice. In particular, people find connections between frogs' tweets, activities and the weather. There is a close relationship between the changes in the rain and frogs' tweets, activities. Therefore, people believe that the frog has some mysterious attributes and believe that it can dominate the rain. Therefore, people want to worship the frog. So people hope the favorable climatic weathers, not droughts and floods. Another point is that under the conditions of low productivity and poor living conditions, Zhuang ancestors prayed for more happiness comes with more offsprings. We know that the reproduction of human beings is the foundation of the existence and development of human society. The output of the means of subsistence for survival is equal to the productivity per capita multiplied by the number of people. In the case that productivity cannot be improved, only the production of the 
people themselves can be strengthened. Based on this idea, the Zhuang ancestors also saw that the frogs have strong reproductive ability, which is in line with their multi-child, multi-blessing psychology. Therefore, they worship it, this vigorous reproductive ability can be transferred to human beings.

Maguai culture has been a flourishing tradition for the Zhuang people alongside the Hongshui River of Guangxi. Maguai, in Zhuang dialect the name for frog, is considered sacred for the Zhuang ethnic group.

Tian'e, a county of Guangxi Zhuang autonomous region, might be the place where Maguai culture is best preserved.

Tian'e has made great efforts to preserve and promote the custom. In recent years, the county has held Maguai folk custom and tourism festival each year to attract visitors.

Maguai festival of Zhuang ethnic group has been included as one of China's national intangible cultural heritages since 2005.

Today's Maguai Festival also brings a rich festive atmosphere, and its frog worship still runs through it. The Maguai Festival is divided into four phases:

1. Ya Yahgvej, on the early morning of the first day of the first lunar month, the young and old are dispatched together, and they flock to the fields to find frogs. Whoever find the first frog become the son-in-law of the Thunder God, called “Maguai Lang”(蚂拐郎), 
naturally become the cavern by the main sacrifice and lead singer (or by the old singer) "A song of Maguai", if the child find it, the father and brother will replace it. After finding the Maguai, the local cannons sound seven times, and the gods and people are announced to "kick the marriage" by the priests. After it , the frog is sealed by the Maguai Lang(蚂拐郎)to the coffin (a golden old bamboo) and put in the flower building, and finally put the flower building in the "gazebo" (lajcax) in the village, accompanied by gongs and drums, firecrackers.

2. Yang Yahgvej, from the first night of the lunar year to the eve of the burial of the frog, every night, every household must go to the "gazebo" to guard the spirit, and hold various worshipping ceremonies, called "playing the pavilion" (caemz lajcax). At first, the priest or the old master of the village sing a song to praise for the frog's virtue, and then the bronze drums ring. The young people dance the Maguai dance, the copper dance, and sing traditional songs, but the content of the songs are different from the songs of the general songs, there are very few love songs, mostly "question songs" and "guess songs". The purpose is to compare the songs, impart knowledge, train singers, this is also the reason the Zhuang folk songs pass down from generation to generation, singers for the endless stream. This type of singing and dancing often last until 
midnight.

3. Mo Yahgvej, accompanied by children, sing the song of the Maguai, accompanying Maguai to walk through villages, the children are holding the flower building, singing the songs of the Maguai, and most of them are the lyrics of auspicious prayers. Each family give packets and sacrifices to the Maguai, until the sunset, the day of the activities is over, the attaining objects are auspicious things, or give people, or for the sacrifices of frogs, in the process, the time and location of the ceremony of the burial of the frog is announced .

4. Gaem Yahgvej, this is the end of the festival, and it is also the climax. Every household make a meal, dress up, paint the sun, the moon, the stars, the pigs, the cow flags, and send the Maguai to the land of the burial of the frog with gongs and drums, firecrackers and singing, dancing . And people carry out "frog divination ": observe the bones of the frog. If it is gray or black, they think it is ominous, then they pray for protection of the frog god. If it is white, it will be a bumper harvest of cotton. If it is golden yellow, it will be auspicious, and the grain will be a bumper harvest. Immediately, the cheers ,the gongs, the drums are heard. This "frog divination " color has a direct relationship with the weather changing, reflected the trend of the climate in some aspects, and it is not 
unreasonable to predict the annual development. After the end of the burial of the frog, it is a "burial meal" and singing, and the singing and the dancing are very grand, often all night long.

The whole Maguai Festival is full of enthusiasm, and the piety of it can be seen from the traces of religious rituals, reflected a strong religious atmosphere. Obviously, the frog god is a totem closely related to agricultural production and population production. The Maguai Festival is a spring worshipping for the frog god.

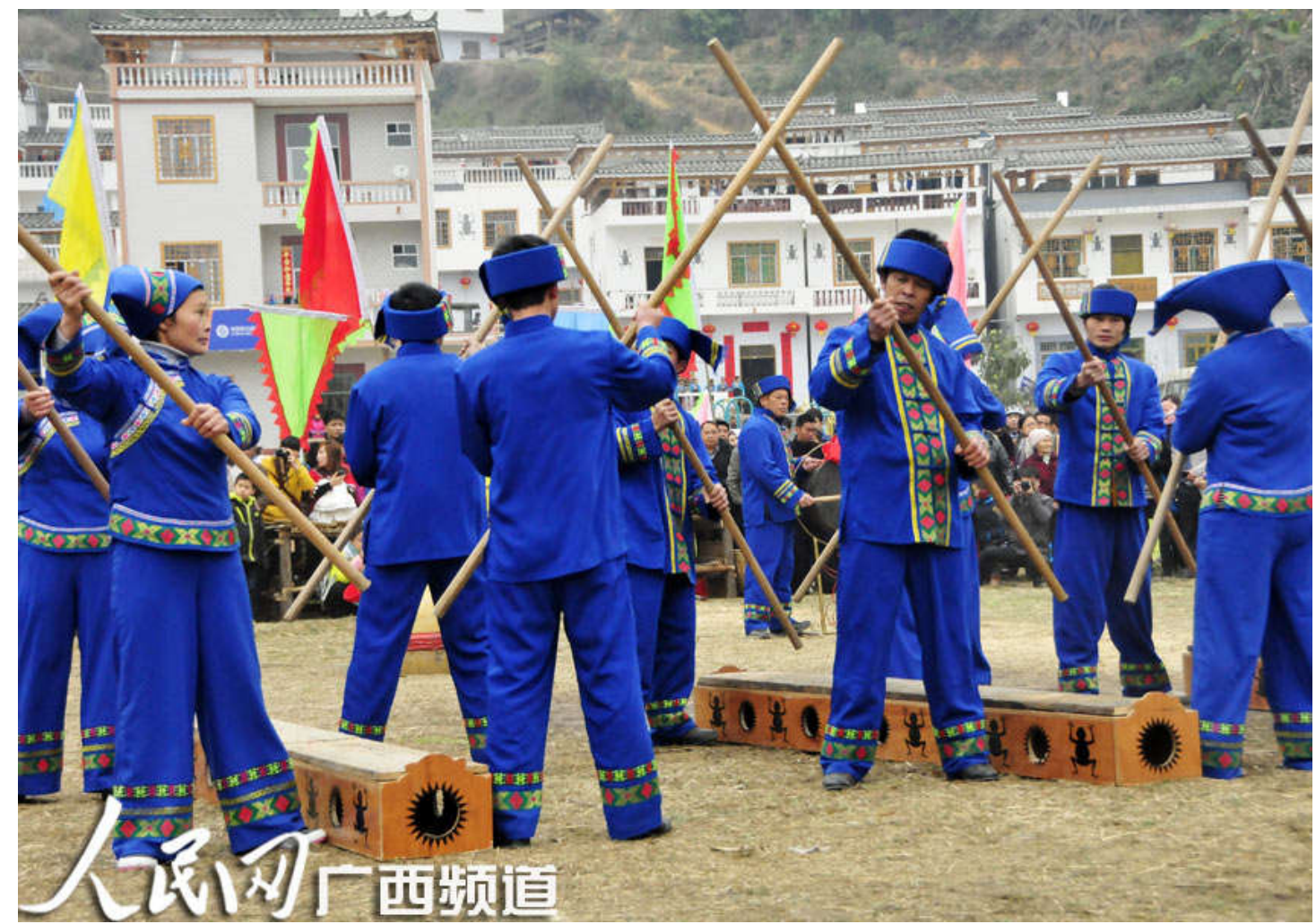

The frog is sealed to the coffin (a golden old bamboo) 


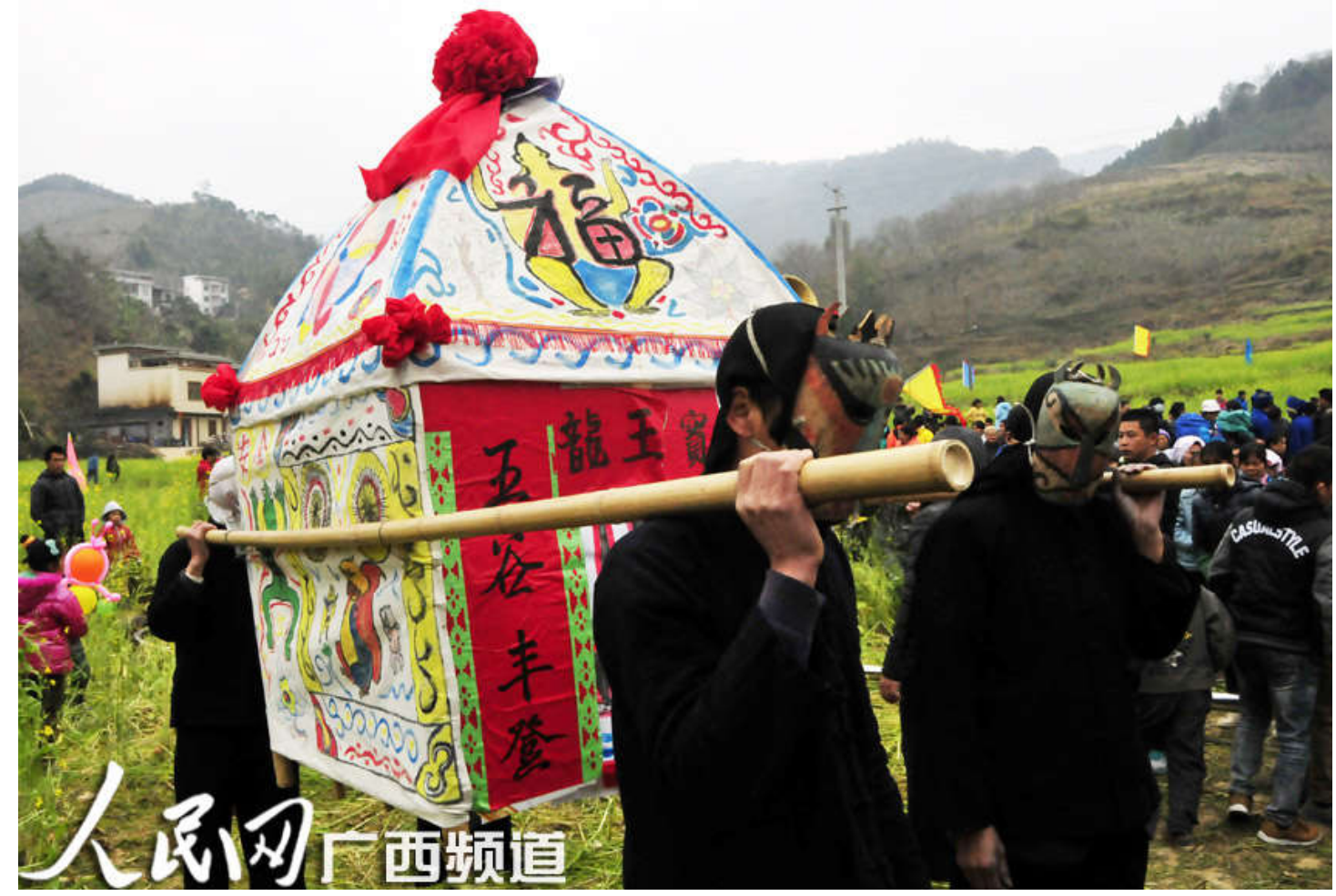

The opening of sacrifice activity

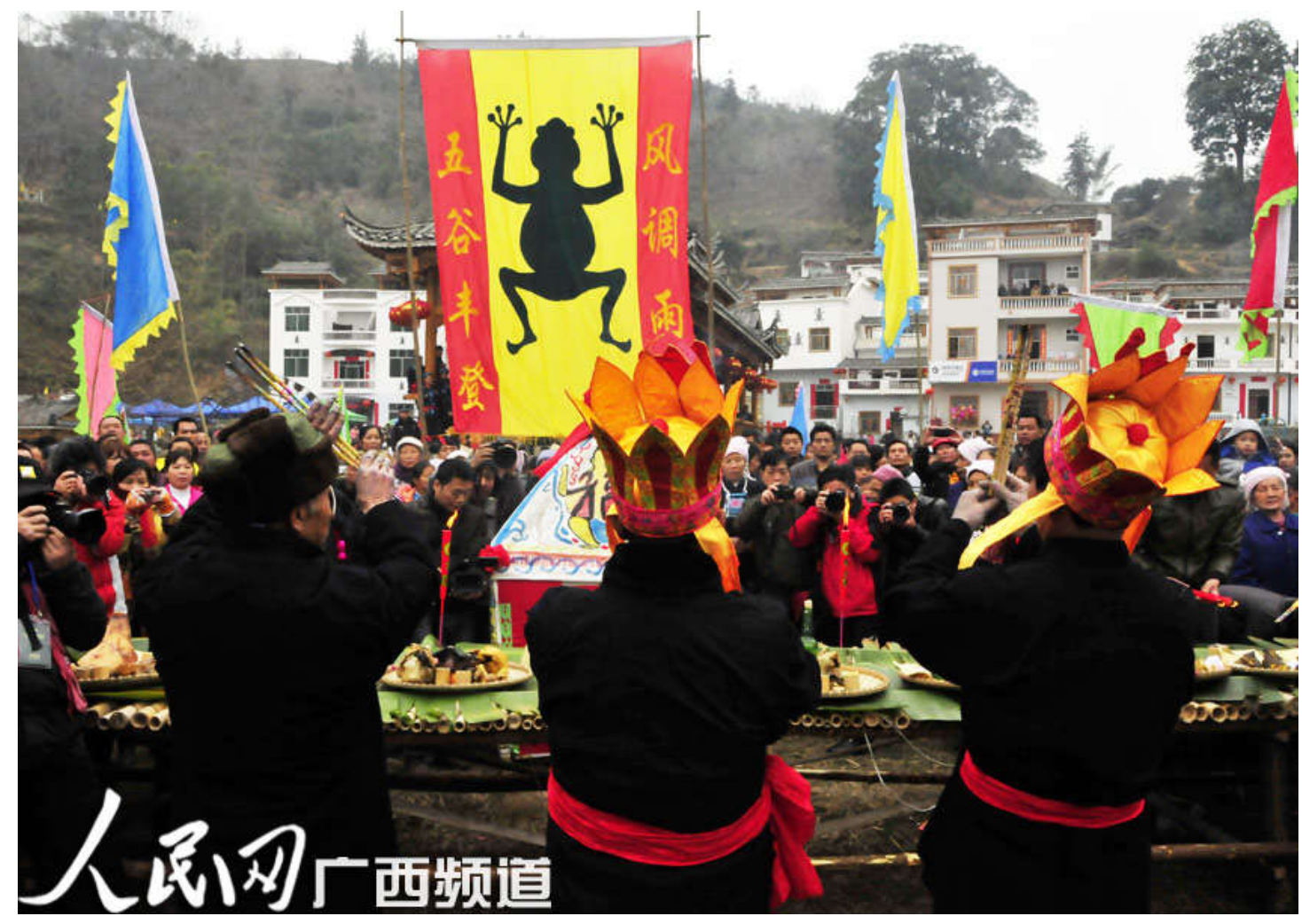

Elders burn incense to worship Maguai 


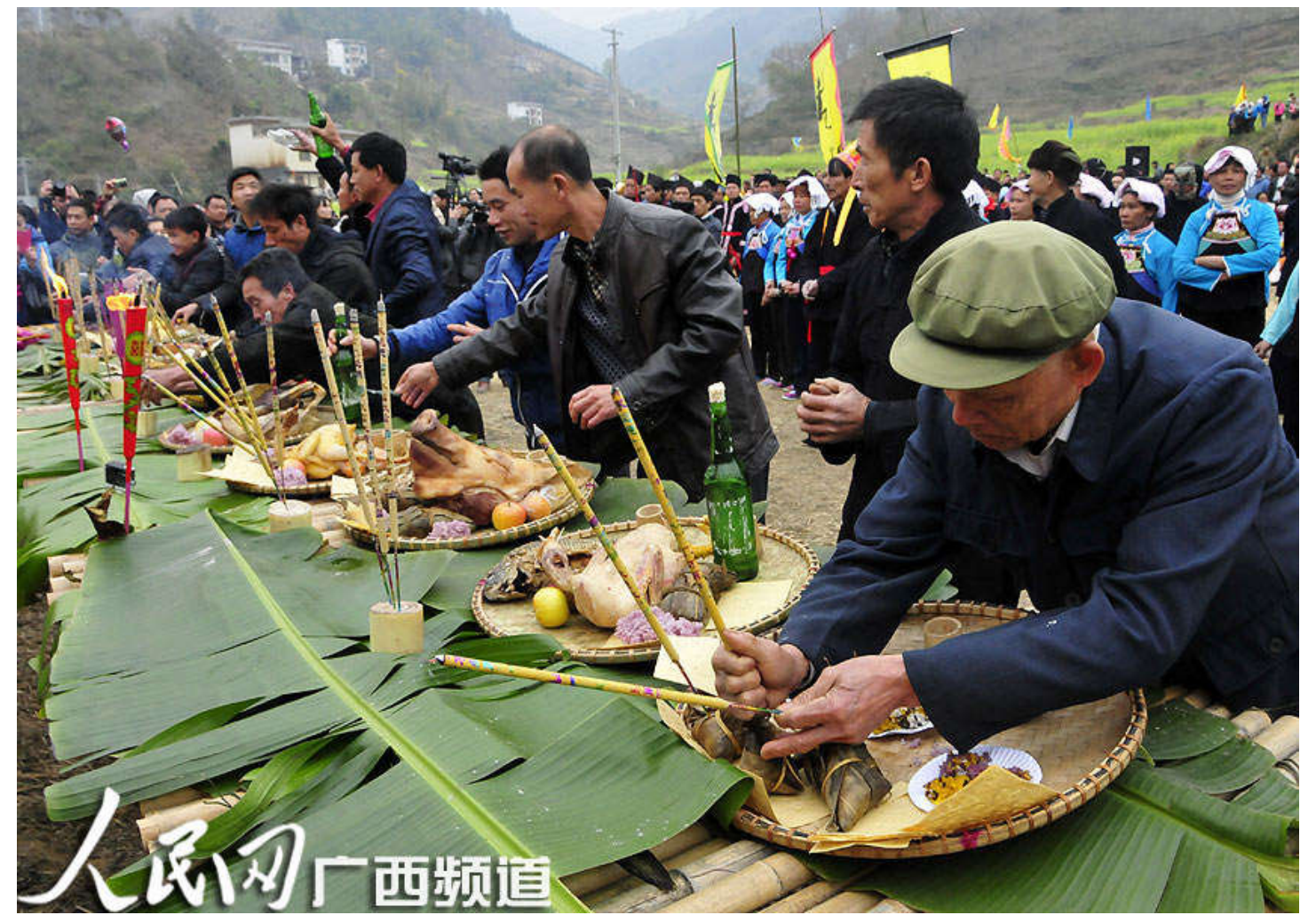

Villagers burn incense to worship Maguai

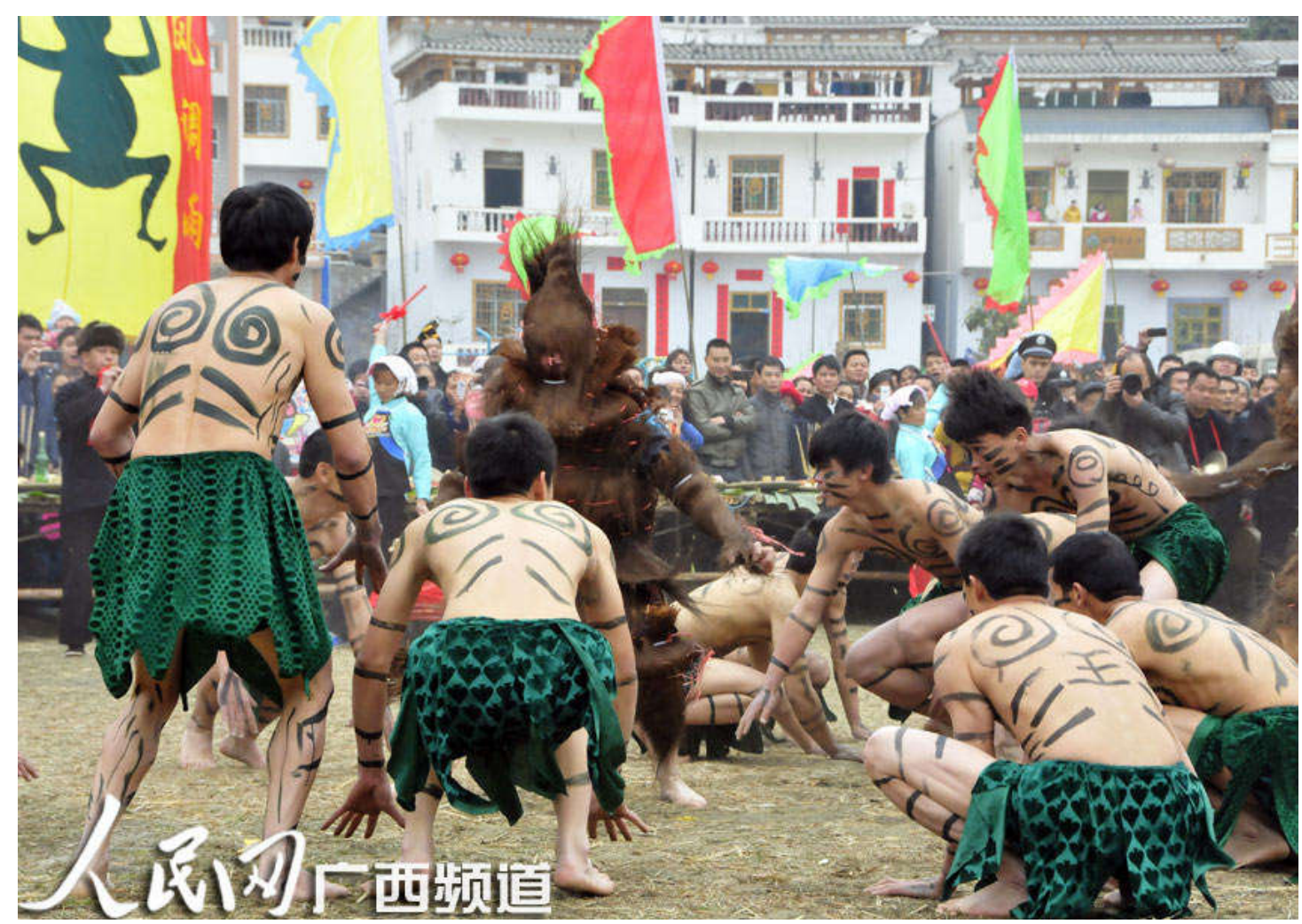

Maguai dance 


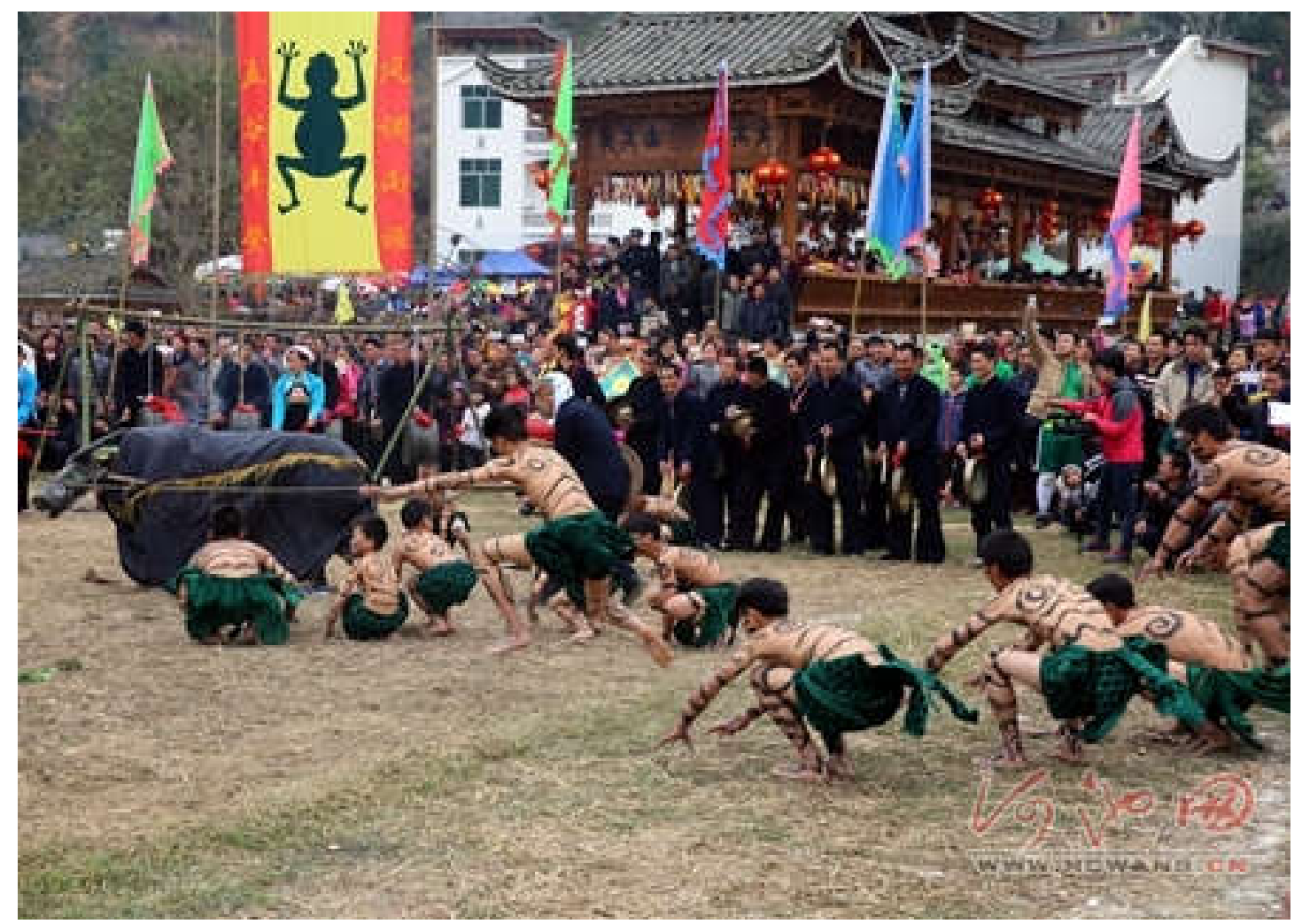

Maguai dance

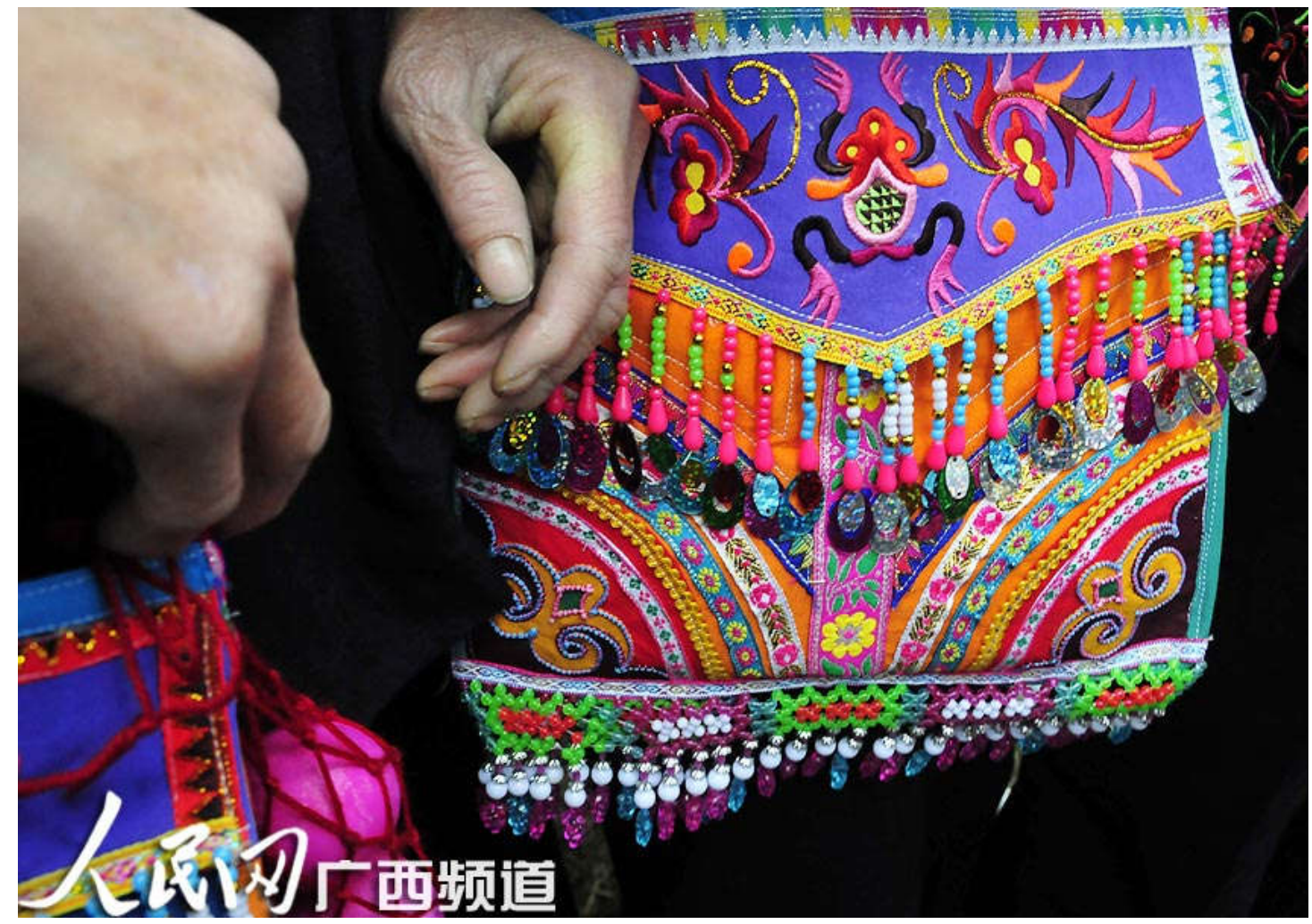

Amulets of Maguai in the bag 


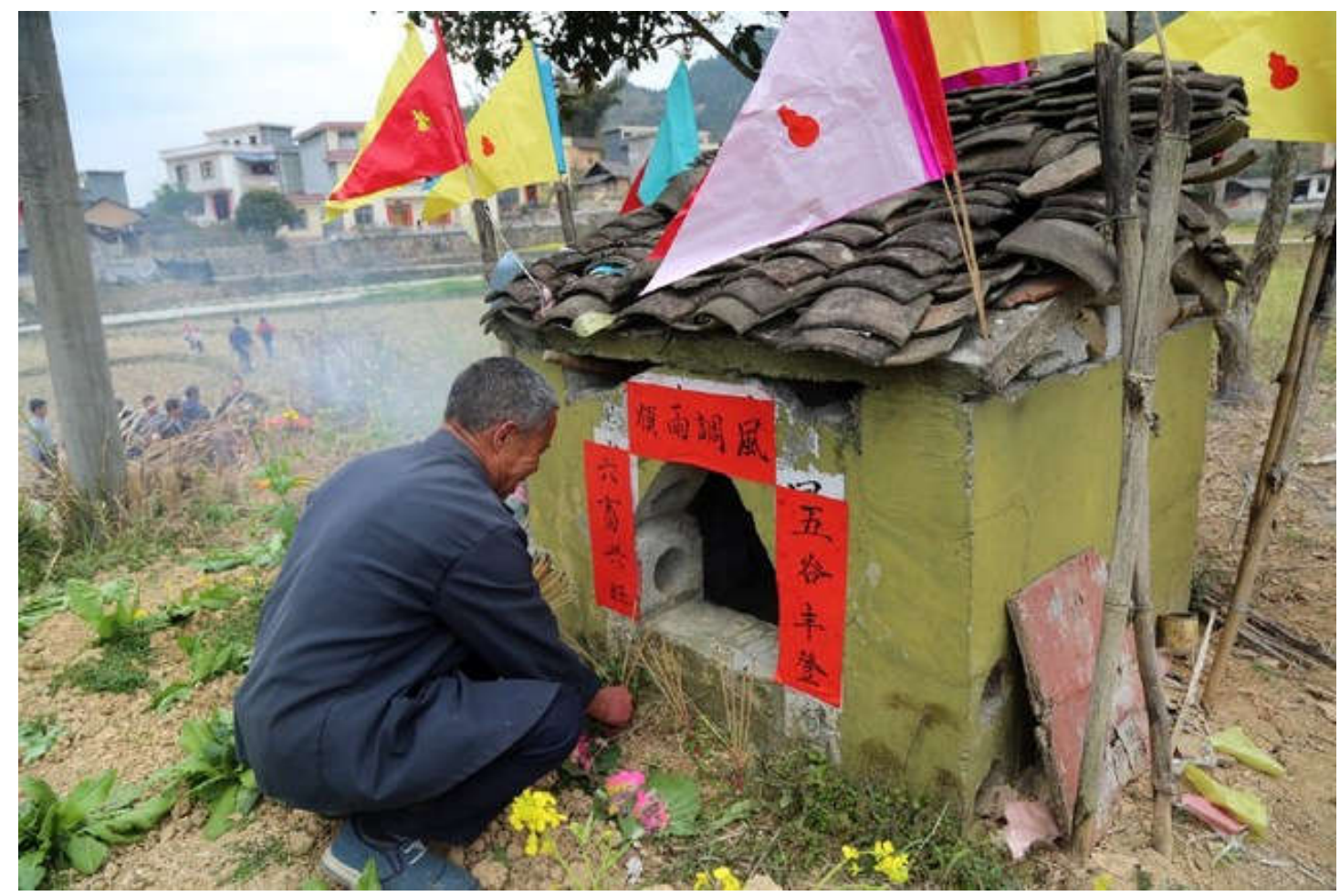

The location where Maguai is buried

Now let us go back to Eygpt. Heqet (Egyptian ḥqt, also ḥqtyt "Heqtit") is an Egyptian goddess of fertility, identified with Hathor, represented in the form of a frog, or a woman with the head of a frog. To the Egyptians, the frog was an ancient symbol of fertility, related to the annual flooding of the Nile.(It is similar to the people worship Maguai to wish for a good harvest). It has been proposed that her name is the origin of the name of Hecate, the Greek goddess of witchcraft.

The name is written as hqt with the determinative "frog". The phonetic spelling may use the biliteral hq hieroglyph in place of uniliteral $h$. The alternative form hatyt adds an explicit feminine ending, used alongside the "egg" determinative to emphasize the deity's femininity. The Middle Egyptian pronunciation of the name may have been close to/ha'qa:tat/, which has been proposed (among other 
possibilities) as the origin of the name of Greek Hecate ('Ekótn). (Heqet is similar to Maguai in pronunciation).

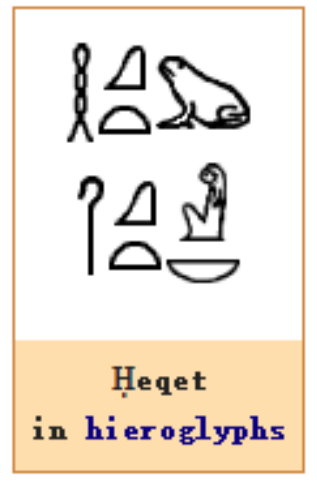

The beginning of her cult dates to the early dynastic period at least. Her name was part of the names of some high-born Second Dynasty individuals buried at Helwan and was mentioned on a stela of Wepemnofret and in the Pyramid Texts.(It is similar to elders burn incense to worship Maguai , because elders often have a high position in Zhuang ethnic group). Early frog statuettes are often thought to be depictions of her.

Heqet was thought to be the wife of Khnum, the god who created men on his potter's wheel, and Heqet gave the newly created being the breath of life before the child was placed to grow in the mother's womb. She was also regarded as the wife of Horus the Elder in the myths of Osiris - she was represented at the funeral as a frog, symbolic of life and fertility after death.( It is similar to the frog is sealed to the coffin (a golden old bamboo) in Maguai Festival).

In the story of the triplets who would be pharaohs, she was the 
goddess of magically "hastens the birth", in an unspecified manner.

In Hatshepsut's (1473-1458 BC) birth colonnade, it was Heqet, with Khnum, who led Ahmose to the birthing room. She also was depicted as the goddess who held the ankh sign of life to Hatshepsut and her $k a$, fulfilling her job as the giver of life to the newly created child. (It is similar to Zhuang people think Frog God has boundless supernatural power).

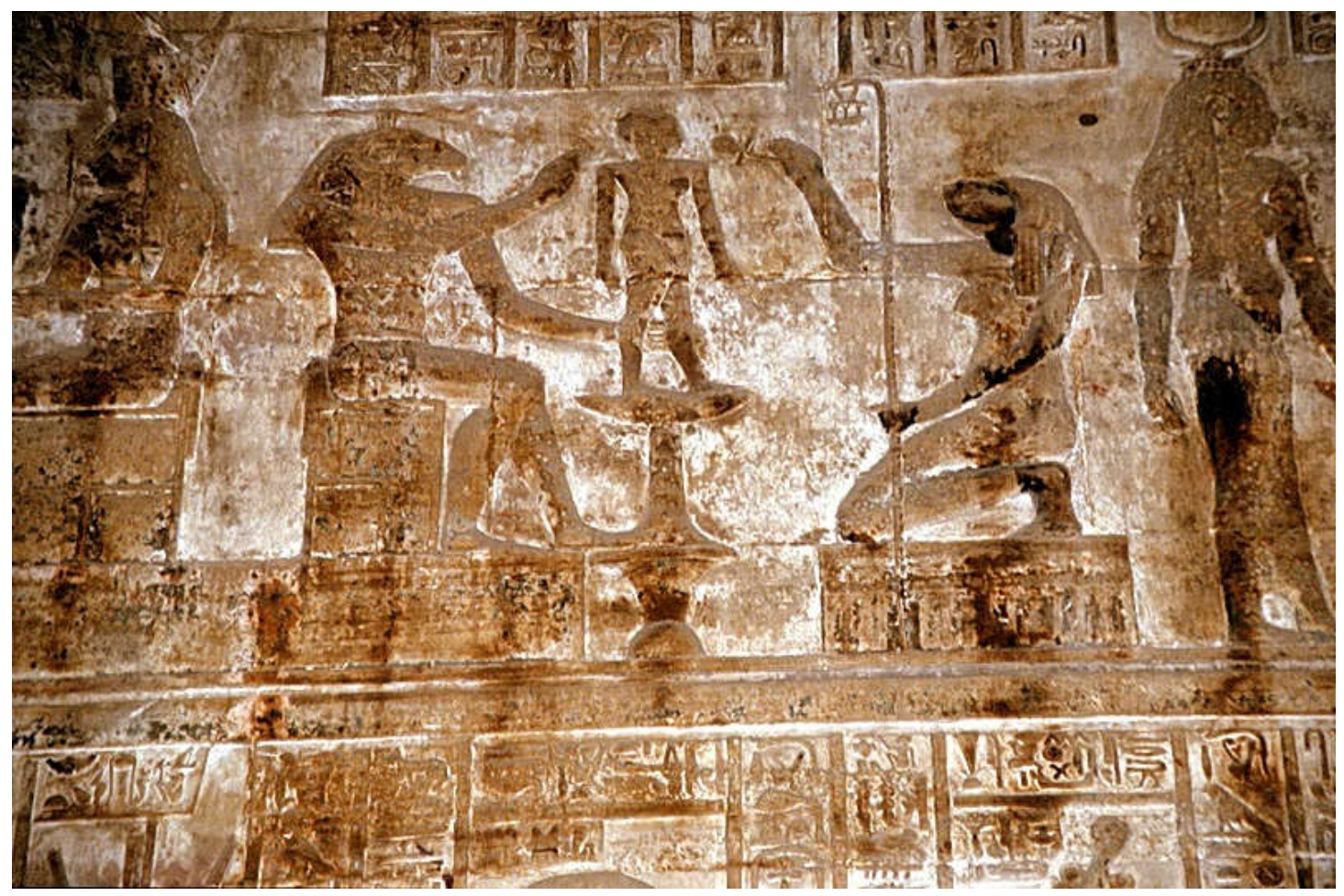

The god Khnum, accompanied by Heqet, moulds Ihy in a relief from the mammisi (birth temple) at Dendera Temple complex.

She originally appears in the pyramid texts where she helps the pharaoh ascend into the sky (Pyramid Text 1312). She is also connected with the Osiris myth in the "Funeral of Osiris" at lunet (Dendera):

Osiris, ithyphallic and bearded, in mummied form, lying upon his bier; over his feet and his body hover two hawks. At the head kneels Hathor, "Mistress of Amentet, who weepeth for her brother," and at the foot is a frog, symbol of the goddess Heqet, beneath the bier are an ibis-headed god holding the Wedjat [Eye of Horus or Ra], two 
serpents, and the god Bes.

-- Wallis Budge, E.A. 1904, Gods of the Egyptians: Volume 2, p. 136

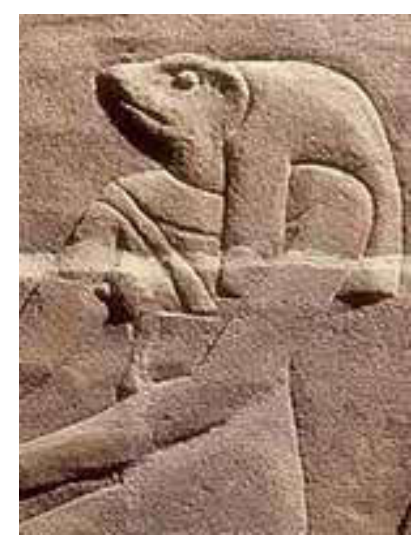

The goddess Heqet

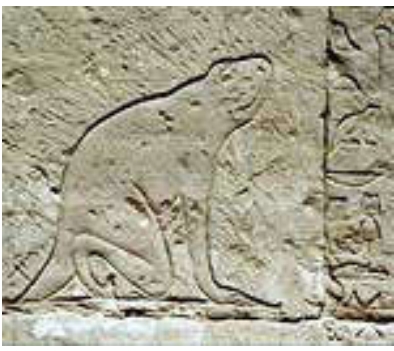

Heqet as a frog

As such, she was not only a goddess of birth, but of rebirth, because of

her life-giving powers: (It is similar to the human soul can be attached to the Frog God in China, besides, the soul after death will return to the totem of Frog God in China ).

As the birth of Horus became more intimately associated with the resurrection of Osiris, so Heqet's role became one more closely associated with resurrection. Eventually, this association led to her amulets gaining the phrase 'I am the resurrection', and consequently the amulets were used by early Christians.

-- Wikipedia, Heqet

As a fertility goddess, associated explicitly with the last stages of the flooding of the Nile, and so with the germination of corn, she became associated with the final stages of childbirth. This association, which appears to have arisen during the Middle Kingdom, gained her the 
title She who hastens the birth (cf. the role of Heqet in the story of The Birth of the Royal Children from the Westcar Papyrus). Some say that-even though no ancient Egyptian term for "midwife" is known for certain-midwives often called themselves the Servants of Heqet, and that her priestesses were trained in midwifery. Women often wore amulets of her during childbirth, which depicted Heqet as a frog, sitting in a lotus. (It is similar to Zhuang ancestors prayed for more happiness comes with more offsprings ). During the Middle Kingdom ritual ivory knives and clappers (a type of percussional musical instrument) bore her name or image as protection for inside the home. She was also sometimes shown on the ivory 'magic wands', which were also linked to the childbirth-related deities Bes and Taweret, and probably used to ward off evil. On such items she was often called the "defender of the home".(It resembles Maguai God has boundless supernatural power, so people take amulets of Maguai in the bag to ward off evil). 


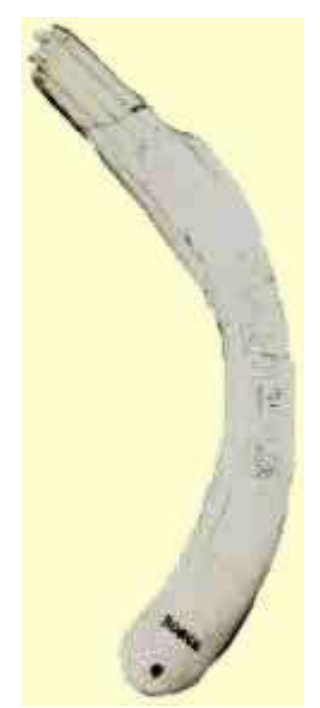

Amulet of Heqet

She was known as "Lady of Her-wer" (Antinoe); a tomb at Tuna el-Gebel has text speaks about a procession in her honour where she asks that the temple of Heqet at Her-wer be restored and protected from inundation, but this temple has not been discovered. Ironically, her temples may not have been discovered due to the fact that, as recorded by Petosiris (c. 4th century $\mathrm{BC}$ ), that her temple was very close to the Nile and had flooded (she subsequently had a temple rebuilt with a retaining wall to keep it safe from future floods):

Now when I was before this goddess, Heqet, lady of Herwer, At her beautiful feast of the year's last month, I being controller of Thoth, She went to a spot in the north of this town, To "House of Heqet," as it is called by all, Which was ruined since time immemorial. The water had carried it off every year, Till its foundation plan was no longer seen, It only was called "House of Heqet," While no brick nor stone was there, Then the goddess halted there. I summoned the temple scribe of this goddess, I gave him silver without counting, 
To make a monument there from that day.

I built a great rampart around it,

So that the water could not carry it off.

I was diligent in consulting the scholars,

So as to organise the rites,

By which this goddess is served,

And content her till she knew it was done.

-- Miriam Lichtheim (1980), Ancient Egyptian Literature: Volume III: The Late Period, pp. 47-48 (It is similar to the speech during worshipping Maguai.)

Her cult was active during the Early Dynastic period and a Second Dynasty prince had her name as part of his own - Nisu-Heqet. During the Middle Kingdom, Papyrus UC 32204 mentions a "manager of the temple of Heqet, Pepi", however this temple has also not yet been found. There was a Ptolemaic temple to Heqet at Gesy (Qus), of which only a pylon remains, where she was paired with the god Horus the Elder.

Heqet was thus an important deity in the daily life of the Egyptian people, in particular for that of Egypt's women, be they queens or commoners, midwives, mothers or mothers-to-be. (It resembles many Zhuang women take amulets of Maguai in the bag to ward off evil). 


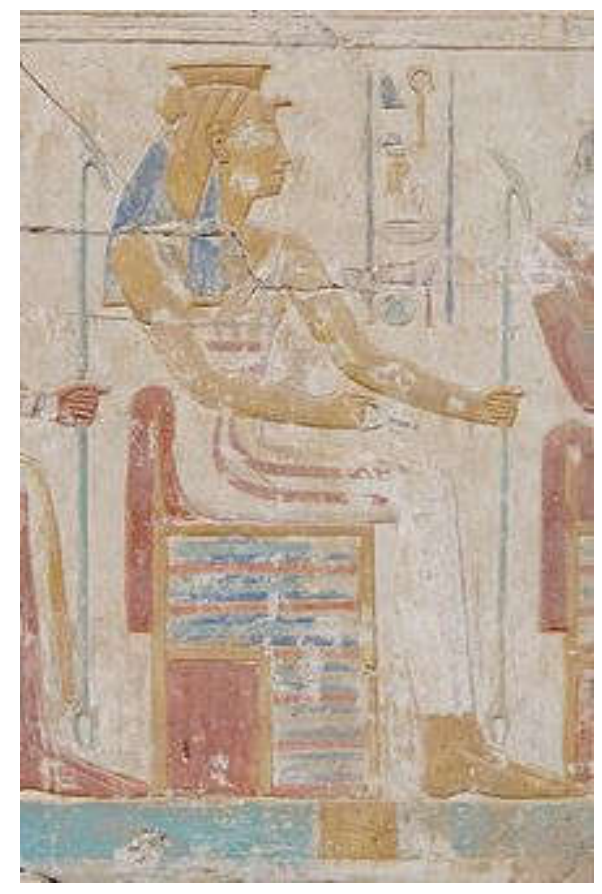

Anthropomorphic depiction of Heqet in the temple relief of Ramesses II in Abydos

So dear readers, from the paper, can't you speculate that Maguai God(Frog God) is actually Egyptian goddess Heqet in China?

\section{References:}

1. http://www.chinadaily.com.cn/m/guangxi/hechi/2017-07/17/con tent_30136569.htm

2. http://www.rauz.net.cn/Article/faenzcieng/mboengqcanghhag/g uhhagdaengxcungj/200703/303.html（蛙图腾是壮民族历史的 烙印)

3. http://usa.chinadaily.com.cn/culture/2016-12/03/content_27559 774.htm\#Content

4. http://www.chinadaily.com.cn/m/guangxi/hechi/2016-02/24/con tent_23625755.htm 
5. http://gx.people.com.cn/n/2014/0212/c179430-20551745-21.h tml（高清组图：广西民俗 “活化石” 壮族蚂拐节全揭秘）

6. https://baijiahao $\cdot$ baidu.com/s?id=1593702007529314949\&wfr=s pider\&for=pc（这里的壮族群众把青蛙视为神, 祭祀活动盛大 壮观）

7. https://en.wikipedia.org/wiki/Heqet

8. http://www.thekeep.org/ kunoichi/kunoichi/themestream/heqe t.html\#.W9fei8t91rR

9. http://www.touregypt.net/featurestories/heqet.htm 